\title{
ON THE WRONG SIDE OF THE TRACKS? Ethical Considerations of the Needle Black Market
}

SINCE THE LATE 1980S, NEEDLE EXCHANGE PROGRAMS (NEPS) HAVE BEEN GREAT RESOURCES FOR INTRAVENOUS DRUG USERS (IDUS), AS THEY PROVIDE BOTH CLEAN NEEDLES WITH WHICH IDUS CAN INJECT AS WELL AS BASIC HEALTH SERVICES, INCLUDING HIV TESTING AND COUNSELING. HOWEVER, FOR REASONS SUCH AS INCONVENIENCE AND FEAR OF CRIMINALIZATION, MANY IDUS OPT INSTEAD TO PURCHASE THEIR NEEDLES FROM ILLICIT STREET SELLERS WHO ACQUIRE NEEDLES IN BULK FROM NEPS. THIS ESSAY CONSIDERS THE ETHICAL PERMISSIBILITY OF THE SELLERS' ACTIONS, FOCUSING SPECIFICALLY ON THE CASE OF A MAN FROM PHILADELPHIA WHO USES THE MONEY HE OBTAINS FROM NEEDLE RESALE TO FEED HIS ADDICTION. IT IS ULTIMATELY ARGUED THAT THE MAN'S ACTIONS ARE, IN FACT, ETHICAL, AS HIS RESALE OF NEEDLES POSITIVELY CONTRIBUTES TO THE COMMON GOOD BY REDUCING THE SPREAD OF DISEASE. ILLICIT NEEDLE SELLERS SUCH AS THE ONE DESCRIBED IN THIS ESSAY SHOULD BE EMBRACED BY THE PUBLIC HEALTH COMMUNITY SINCE, WITH PROPER TRAINING, THEY CAN HELP TO FACILITATE HEALTH PROMOTING EDUCATION FOR THEIR PEERS. 
9 Every Friday afternoon, men and women of all ages gather in the hallways of Prevention Point Philadelphia to exchange their used needles for new ones. For each dirty needle a user brings, they receive one clean needle in return. While many participants come to Prevention Point with just a few needles to exchange, others come with hundreds. Many resell the needles they receive from Prevention Point on the street of Philadelphia.

One Prevention Point client, who will be referred to in this essay as Michael, resells the clean needles only a half-mile from the site of the needle exchange program. He has chosen this territory because it is a block away from where users buy and shoot drugs and so the clientele are desperate. The needles sell for a dollar per piece, and with enough needles sold, Michael can afford to buy himself a bag of dope. While the resale of needles is illegal in Pennsylvania, Philadelphia law enforcement is tolerant toward black market sellers like Michael.

In this country alone, approximately 800,000 individuals aged I3 or older inject drugs each year. ${ }^{2}$ These intravenous drug users (IDUs) are at high risk of HIV infection, as injection is a major route of transmission of the disease. In fact, about $7 \%$ of the estimated 47,352 diagnoses of HIV in 2013 were attributed to intravenous drug use, with an additional $3 \%$ attributed to a combination of male-to-male sexual contact and IDU. ${ }^{3}$ In Philadelphia, the rates of infection via injection are similar to those of the nation, with $7.7 \%$ of AIDS cases and $4.4 \%$ of HIV cases diagnosed in 2013 resulting from infected needle sharing. ${ }^{4}$ As an urban

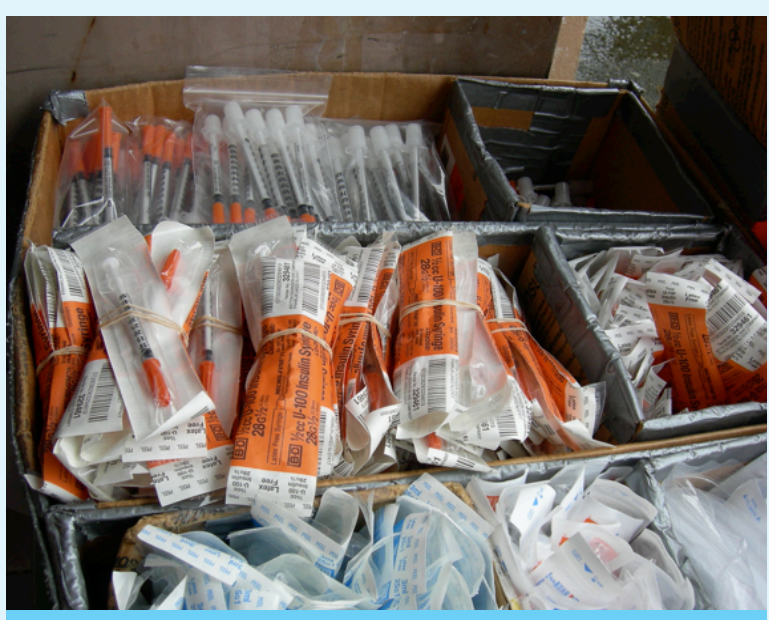

CLEAN HYPODERMIC NEEDLES AND SUPPLIES FOR INJECTION (COURTESY OF WIKIMEDIA COMMONS) city, Philadelphia has approximately 26,400 IDUs in its population of I.5 million. ${ }^{5}$

A large percentage of IDUs throughout the United States obtain at least some of their needles from illicit salespeople on the street. ${ }^{6}$ For example, in Baltimore, Maryland, which is just two hours away from Philadelphia by car, $85 \%$ of IDUs obtain a number of their needles from street sellers despite the existence of well-established needle exchange programs. ${ }^{7}$ These IDUs purchase needles from illicit sellers due to the convenience of the exchange as well as their fear of criminalization and stigmatization. Although concerns about the sterility of these needles sold on the street do exist, studies have shown that these needles are generally safe. In some cities, there even exists self-policing where sellers hold each other accountable for distributing clean needles. In Washington D.C., for instance, the resale of used needles is disparaged by most sellers, and those who do sell used needles face backlash from their peers. ${ }^{8}$ Therefore, the disease risk associated with street purchases is relatively low.

Prevention Point Philadelphia (PPP), the needle exchange program from which Michael obtains his needles, has been in operation since I99I and is recognized by the city of Philadelphia as a major reason for the decline of HIV/ AIDS diagnoses among IDUs. Since 2004, the IDU population of Philadelphia experienced a decrease in infection rates of more than two-thirds, the greatest drop among all high-risk groups (i.e., IDUs, men who have sex with men, and high-risk heterosexuals). 9 PPP attributes this drop not only to the clean needles they provide at the exchange, but also to the health care, safe needle education, HIV testing, case management, and referrals to drug treatment they offer. ${ }^{10}$ However, the organization recognizes that its reach is limited, as some users are unwilling to visit the exchange due to the stigma associated with injection drug use, while others simply find it inconvenient. These individuals constitute Michael's market.

In the United States and elsewhere, intravenous drug use is oftentimes considered a marker of dissolute character. Intravenous drug users are considered to be social deviants, and, as a result, are subjected to discrimination and exclusion. The United Nations notes, "A system appears to have been created in which those who fall into the web of addiction find themselves excluded and marginalized from the social mainstream [and] tainted with a moral stigma." ${ }^{\text {II }}$ Intravenous drug users must navigate this environment of marginalization and stigmatization, and they 
most commonly do so by skirting to the edges and remaining unseen. They may avoid the shame of stigma through hiding, but this retreat inhibits IDUs from receiving the help that they need. As a woman interviewed on the streets of Philadelphia admits, "I haven't talked to [my family] since I've been down here for a month and a half now. I just...I'm too embarrassed, I guess, to call. That's all I want to do, though, is call them 'cause I know they'd be there for me in a heartbeat, but I'm just too...too ashamed." ${ }^{22}$

The criminalization of illicit drugs also contributes to IDUs' desire to remain out of sight. In fact, the Joint United Nations Program on HIV/AIDS (UNAIDS) considers criminalization to be the number one reason why IDUs are being left behind, as fear of arrest deters IDUs from accessing HIV and other drug-related services..$^{13}$ However, considering Michael's story, it seems as though the situation in Philadelphia is uniquely different. The practice of needle resale remains largely unpunished in the city, allowing Michael and others to sell needles with little fear of repercussion. Indeed, Philadelphia has what the media has referred to as a "cop-free heroin zone," ${ }^{4} 4$ where hundreds of addicts congregate to publicly buy and do drugs. In these areas, and specifically on Philadelphia's Kensington Avenue, it is not uncommon to openly sell needles and prescription pills to hustle enough money for a bag of heroin. ${ }^{15}$ While the Philadelphia Police Department claims that this cop-free zone does not exist, Michael and his fellow IDUs who spend their days and nights hustling and injecting on the street prove otherwise. ${ }^{16}$

Unlike the sale of drugs themselves, it seems that the sale of needles contributes positively to the common good, which is defined as "the sum total of the conditions of social living whereby persons are able to reach their perfection." ${ }^{\text {17 }}$ On Kensington Avenue and the nearby "Tracks," ${ }^{18}$ a stretch of wooded railway commonly inhabited by IDUs, used and possibly infected needles can be found by the hundreds on the ground. A desperate addict looking for a fix could very easily use one of these needles to inject; alternatively, he could share a needle with a fellow addict who might very well be HIV positive. In anthropologist Philippe Bourgois's book Righteous Dopefiend, a man named Frank tells of his experience with needle sharing: "We always try not to share needles but we still do it. Hey, if you're sick you're not gonna worry about it. When you gotta fix, you gotta fix." ${ }^{19}$ What Michael is doing, then, is providing needles exactly where they need to be at exactly the right time- - to those addicts on the streets when they need a fix, right before they go to inject. He also removes hundreds of used needles from the streets by collecting them for trade at the exchange, thus contributing further to the common good by fostering a clean environment. In fact, Michael's actions have even received praise from public health officials in the city of Philadelphia; they note that "Philadelphia's strong network of people spreading needles from the exchange plays a big role [in the drop of new diagnoses of HIV]." ${ }^{20}$

Thus, city officials in Philadelphia have shifted their focus from policing the exchange of needles to keeping people healthy. ${ }^{21}$ The city of San Francisco, meanwhile, attempted the opposite approach, but it proved to have detrimental effects on the city's IDU population. In I997, San Francisco mayor Willie Brown instituted a zero-tolerance drug policy under which anyone carrying more than two needles could be charged with "possession of controlled paraphernalia with intent to sell," ${ }^{22}$ a felony charge. As a result, the homeless IDU population stopped carrying multiple needles at a time, thus reducing their stash and fostering the sharing and reusing of needles. ${ }^{23}$ In addition, they stopped their frequent visits to their local needle exchange program, which was their source of not only clean needles but also basic health services. ${ }^{24}$ Mayor Brown's actions proved to be a public health catastrophe, encouraging high-risk behaviors and discouraging treatment. The unjust criminal system proved detrimental to the population of homeless IDUs in the city. Indeed, his criminalization of needle possession serves as an example of structural violence.

It seems, then, that Philadelphia should be commended for essentially decriminalizing illicit needle resale and possession. In fact, Michael's sale of needles on Kensington Avenue does not seem fundamentally different from the legal sale of needles at pharmacies throughout the city. In 2009, the Pennsylvania Board of Pharmacy adopted an amendment allowing needles and syringes to be sold at pharmacies throughout the state without a prescription..$^{25}$ The justification for this amendment was harm reduction and the promotion of public health. This same rationale could be used to defend Michael's actions. Although Michael's motives are selfish, he nonetheless "fills an important risk reduction niche" in Philadelphia by meeting the demand for clean needles in a way that Prevention Point and local pharmacies cannot. ${ }^{26}$

Although he ultimately contributes to the common good, there are a number of ethical questions that one might 


\section{"In alignment with the principle of subsidiarity...public health initiatives could be designed to train illicit needle sellers to provide their clients with health promoting education."}

grapple with when considering the morality of Michael's actions. Examples of possible concerns (C) and corresponding responses $(\mathrm{R})$ are outlined in the following list:

C. Michael is selling what he got for free, which is ethically questionable.

R. In fact, many needle exchange advocates are offended by the resale of free needles. ${ }^{27}$ However, Michael is providing a service to his clients by collecting and exchanging the needles, and, like in any service economy, he should be paid for his work.

C. Michael's resale of needles is simply wrong because it is illegal.

R. As was discussed above, Michael's actions do contribute positively to the common good. Alternatively, he could be stealing or working as a john to support his habit, both of which would be harmful to society. His "opportunistic entrepreneurship," ${ }^{28}$ though illegal, provides clean needles to people who would otherwise inject with a used needle.

C. Michael could be an unreliable seller who is selling used needles.

R. While it is true that Michael could sell used needles as if they were new, he lacks a reason to do so. Since Prevention Point Philadelphia will provide Michael with as many clean needles as he can trade for, he does not lack supply.

C. In typical needle exchange programs, one used needle gets you one clean needle. In Michael's case, one dollar gets you one needle. Maybe people wouldn't otherwise have the needle.

R. If an IDU were to purchase a needle from a pharmacy, it would also entail an exchange of money. If that IDU could not purchase a needle from a pharmacy (or from Michael), he would likely inject with a used needle obtained from a fellow IDU or discarded on the street. As Paul Yabor, a Prevention Point educator and ex-drug addict, notes, "The cold, hard reality is that someone with a habit, or under the influence of [drugs] is going to go to extreme measures to inject." ${ }^{29}$
C. Michael's selling of needles is enabling his own addiction.

R. Any source of income Michael might have would enable his addiction. His selling of needles is not unique in that way.

Above all, in evaluating the morality of Michael's actions, it is necessary to acknowledge that he is exercising the virtue of self-care. Theologian Roger Burggraeve explores a growth ethic in which one must strive for a particular goal, or "ethical optimum," while at least employing the necessary measures, or "ethical minimums," to ensure his or her safety. ${ }^{30}$ Thus, each clean needle that Michael provides must be seen as an "ethical minimum" that upholds the dignity of the needle's recipient and prevents the spread of HIV. $^{3 \mathrm{I}}$ The clean needle allows addicts to remain free of disease as they work toward the "ethical optimum" of ridding themselves of their addiction..$^{32}$ According to Bourgois, many of Philadelphia's addicts will eventually recover, and clean needles protect their health until they do. ${ }^{33}$ Thus, in the long run, Michael's needles contribute positively to the flourishing of others. When the addict is finally able to live a life without drugs, he is also able to live a life without the burden of HIV.

It is problematic, however, that Michael does not provide the health services that the IDU would receive had he vis-

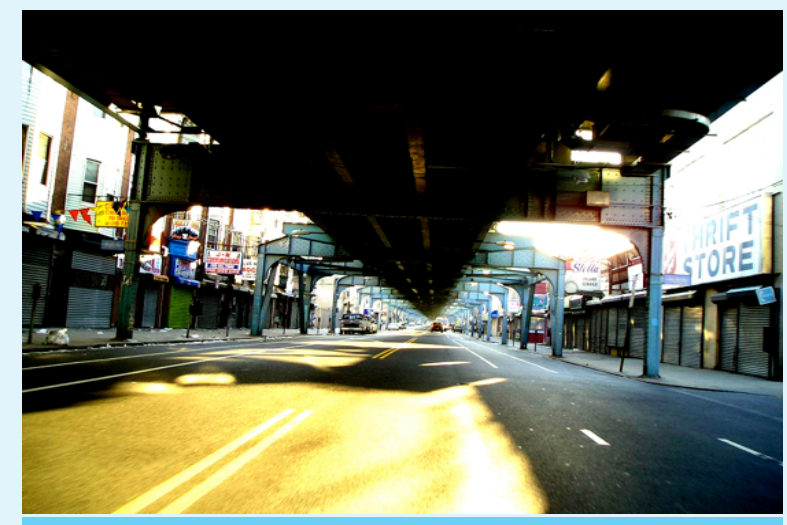

MARKET-FRANKFORD LINE, KENSINGTON AVENUE, PHILADELPHIA PA (COURTESY OF WIKIMEDIA COMMONS) 
ited the needle exchange program himself. ${ }^{34}$ Ideally, each exchange is an opportunity for intervention and the initiation of rehabilitation and recovery processes. Michael does not offer such services to his clients, and, thus, they are less likely to get treatment for their addiction or even discover their HIV status. This lost opportunity should be seized. In alignment with the principle of subsidiarity, which states that matters should be handled at the most immediate level, public health initiatives could be designed to train illicit needle sellers to provide their clients with health promoting education. Since Michael holds an important role in his community and is in such frequent communication with drug users, he has a great opportunity to spread information and be heard.

Despite being recognized as a highly effective harm reduction strategy, needle distribution is a widely disputed topic. The needle black market, then, takes the dispute one step further, as it allows intravenous drug users to profit from the addictions of their peers. Nonetheless, illicit street sellers contribute greatly to their communities by removing used and possibly infected needles from their environment and providing IDUs with clean needles with which they can safely inject. Since 2004, IDUs in the city of Philadelphia have seen an incredible drop in rates of HIV/ AIDS infection, and this is undoubtedly due, at least in part, to Michael and his fellow street sellers. Social and logistical barriers, such as the fear of facing stigma and accommodating hours and location of operation, limit needle exchange programs' and pharmacies' ability to provide IDUs with the materials they need. Street sellers, however, are conveniently located where users are injecting at the very moment they wish to inject. By providing IDUs with clean needles, street sellers protect the addicts' health by ensuring that they do not inject with an infected needle, thus contributing to the common good. Illicit street sellers should be embraced in cities across the United States as individuals who can deliver not only needles, but also important messages regarding harm reduction and even treatment information. Making the best use of these resources is a logical step forward in the effort to improve public health.

\section{ENDNOTES}

I. Jacobs, "Needle Exchange Program", 2015.

2. Lansky et al., "Estimating the Number of Persons Who Inject Drugs", 20I4.

3. Centers for Disease Control and Prevention, "HIV and

Injection Drug Use in the United States", 2015.

4. Lim et al., "Drug Use in Philadelphia", Pennsylvania: 2013, 2014

5. Philadelphia Department of Public Health, "AIDS Activities

Coordinating Office Surveillance Report 2014", 2015.

6. Stopka et al., "Public Health Interventionists", 2003.

7. Ibid.

8. Pierce, “Gen-X Junkie”, I999.

9. Prevention Point Philadelphia, "Myths and Facts". Io. Ibid.

II. United Nations Office on Drugs and Crime, "2008 World Drug Report”, 2008

I2. Deeney, "Philly's Cop-Free Heroin Zone", 2 oII.

I3. UNAIDS, "The Gap Report 20I4: People Who Inject Drugs", 20 I4.

I4. Deeney, "Philly's Cop-Free Heroin Zone", 20II.

I5. Ibid.

I6. Ibid.

I7. Doyle Roche, "Children and the Common Good", 2008.

I8. Deeney, "Philly's Cop-Free Heroin Zone", 20II.

I9. Bourgois \& Schonberg, "Righteous Dopefiend", 2009.

20. Jacobs, "Needle Exchange Program", 2015.

2I. Ibid.

22. Bourgois \& Schonberg, "Righteous Dopefiend", 2009.

23. Ibid.

24. Ibid

25. The Pennsylvania Bulletin, "Sales of Hypodermic Needles and Syringes", 2009.

26. Stopka et al., "Public Health Interventionists", 2003.

27. Bourgois \& Schonberg, "Righteous Dopefiend", 2009

28. Ibid.

29. Jacobs, "Needle Exchange Program" 20I5.

30. Cimperman, When God's People Have HIV/AIDS, 2005.

3I. Ibid.

32. Ibid.

33. Jacobs, "Needle Exchange Program", 2015.

34. Prevention Point Philadelphia, "Myths and Facts". 


\section{REFERENCES}

Bourgois, Philippe, and Jeffrey Schonberg. Righteous Dopefiend. Berkley: University of California Press, 2009.

Cimperman, Maria. When God's People Have HIV/AIDS. Maryknoll, NY: Orbis Books, 2005.

Commonwealth of Pennsylvania. "Rules and Regulations: Sales of Hypodermic Needles and Syringes." The Pennsylvania Bulletin, September I2, 2009. http://www.pabulletin.com/secure/data/vol39/39-37/I68I.html.

Deeney, Jeff. "Philly's Cop-Free Heroin Zone." The Daily Beast, last modified August I3, 20II. http://www.thedailybeast.com/articles/20II/08/13/philadelphia-s-kensington-avenue-heroin-prostitution-and-no-police.html.

"HIV and Injection Drug Use in the United States." Centers for Disease Control and Prevention, October 27, 2015. http://www.cdc.gov/hiv/risk/idu.html.

Jacobs, Emma. "Needle Exchange Program Creates Black Market In Clean Syringes.” NPR, January 3, 2015. http:// www.npr.org/20I5/OI/03/37456043I/needle-exchangeprogram-creates-black-market-in-clean-syringes.

Lansky, Amy, Teresa Finlayson, Christopher Johnson, Deborah Holtzman, Cyprian Wejnert, Andrew Mitsch, Deborah Gust, Robert Chen, Yuko Mizuno, and Nicole Crepaz. "Estimating the Number of Persons Who Inject Drugs in the United States by Meta-Analysis to Calculate National Rates of HIV and Hepatitis C Virus Infections." PLOS ONE 9, no. 5 (20I4). doi:Io.I37I/journal.pone.0097596.

Lim, Suet, Roland Lamb, and Marvin Levine. "Drug Use in Philadelphia, Pennsylvania: June 20I3." National Institute on Drug Abuse, November 4, 2013. http://www.drugabuse.gov/about-nida/organization/workgroups-interestgroups-consortia/community-epidemiology-work-groupcewg/philadelphia-pennsylvania.

Philadelphia Department of Public Health. "AIDS Activities Coordinating Office Surveillance Report 20I4."City of Philadelphia (20I5): II. http://www.phila.gov/health/ pdfs/2014\%20Surveillance\%20Report\%2oFinal.pdf.
Pierce, Todd. "Gen-X Junkie: Ethnographic Research with Young White Heroin Users in Washington, DC." Substance Use Q Misuse 34, no I4 (1999): 2107.

Prevention Point Philadelphia. "Myths and Facts." Accessed November I8, 20I5, http://ppponline.org/mythsand-facts.

Roche, Mary Doyle. "Children and the Common Good." In Calling for Justice Throughout the World, edited by Mary Jo Iozzio. New York: Continuum International Publishing Group, 2008.

Stopka, Thomas J., Merrill Singer, Claudia Santelices, and Julie Eiserman. "Public Heath Interventionists, Penny Capitalists, or Sources of Risk?: Assessing Street Syringe Sellers in Hartford, Connecticut." Substance Use \& Misuse 38, no. 9 (2003): 1346.

United Nations AIDS. "The Gap Report 20I4: People Who Inject Drugs.” July 20I4. http://www.unaids.org/sites/default/files/media_asset/05_Peoplewhoinjectdrugs.pdf.

United Nations Office on Drugs and Crime. "2008 World Drug Report.” June 2008. https://www.unodc.org/documents/wdr/WDR_2008/WDR_20o8_eng_web.pdf. 